\title{
WRAPPED IN PLASTIC: Transformation and Alienation in the New Finnish Economy
}

\author{
DAENA AKI FUNAHASHI \\ Columbia University
}

"She worked like mad," said Iiris of her friend Saija as the three of us sat outside of the rehabilitation center not far from Helsinki where Saija attended an in-patient program for occupational burnout (työuupumus). Iiris explained how Saija, a telephone dispatcher for an office machine company, not only did work allotted to her per her job description but also work she picked up as favors for others and odd tasks that no one else volunteered to do. Gently stroking her friend's arm, Iiris turned to me and added, "She doesn't know how to protect herself." While up until then Saija had sat quietly, clasping together her hands, which continued to tremble no matter how tightly she held them, now she spoke up. Saija explained that it was not as if she intended to pick up after her coworkers. Instead, she explained that when they dumped work on her desk, hoping or knowing that she would do it, she felt that she had to do it. "But why?" asked Iiris, still not satisfied. At this, Saija drew in a sharp breath as if to launch a protest, but, instead, sighed, then pursed her lips and fidgeted with her hair with hands that now trembled freely. Iiris quickly handed her some tissue paper, and we all looked away as Saija blew her nose and took off her glasses to wipe her eyes.

Saija's rehabilitation center, like many rehabilitation centers in Finland, lay away from the city center in a secluded place. The director of Saija's program explained the benefits of its location as one in which "rehabilitees can contemplate life away from life, in order to rethink how they can get back into the world." ${ }^{\text {In }}$ emphasizing the return of rehabilitees "back into the world," the director not only 
pointed to the physical return of rehabilitees back into the workforce but also, as the director put it, the "improvement of their functional ability at work."

Such a portrayal of rehabilitees as individuals in need of self-reflection and improvement echoes the objectives of the national blueprint for burnout programs developed by the Finnish Insurance Institution (KELA). KELA, the public agency responsible for providing Finland's social security programs, sees burnout as the "new hazard" of the "new economy" (Lehto 2007). Specifically, it makes visible burnout as an ailment of individual maladaptiveness to neoliberal economic ideals put in place since the economic crisis of the 1990s. KELA's blueprint for rehabilitation is premised on the notion that individuals such as Saija act in ways that fail to consider the "realities" of the new workplace. In the face of a new legitimacy placed on economic reductionism as the rationale for social exchange, Saija's inability to "protect herself" appeared as an idealistic and irresponsible mismanagement of her health. Rehabilitative discourse cast Saija and many others with burnout as overly "conscientious" individuals who must come to be aware of this truth about themselves. KELA's blueprint for rehabilitation is specific on this point. The prevention of further absenteeism from work and social exclusion of individuals with burnout, it says, depends upon the ability of the rehabilitee to improve his or her "self-awareness" (itsetuntemus). ${ }^{2}$ Self-awareness as articulated by KELA includes not only the awareness of limits in professional aptitude and physical limits to stress but also the awareness that one's conceptualization of one's obligations to others and how one operates at work in general constitute the root of distress. KELA's plan takes as its operative frame an “empowerment paradigm” (Hätinen 2008) that defines individual rehabilitees as active partners in their own path to recovery, and that through self-awareness, here made synonymous with self-empowerment, individuals can establish their own limits to work and minimize distress even in a time characterized by increased individuation and competition between workers.

Yet, through joining rehabilitees in their discussions during off-hours of the program, I found that this rehabilitative demand to become more aware of the "self" had unintended consequences. Saija's speechlessness and inability to position herself as the author of her own actions repeated in many other rehabilitees with whom I worked. I see the rehabilitative discourse that represents rehabilitees as individuals in need of improved self-awareness as paradoxically making evident to them that "something" not yet identified nonetheless animates their actions. James Siegel (2006) argues that it is at such moments of deferred identification of the foreign within the self that surety of the self is lost. Although KELA's formulation of burnout makes recognizable__ “naming” in Siegel's terms — this animating force 
as "conscientiousness," I found that this, for the rehabilitees, neither grounds the basis for a new identity to develop nor does it restore the old. Naming what presumably motivated rehabilitees into self-harmful behavior merely supplements the notion that the subject was not fully conscious of and self-possessed of its action, and that it was indeed moved by "something" heretofore unrecognized. Instead, the diagnosis of burnout confers a social logic on the clients' actions - a rationale that makes reasonable sense within the telos of a reified moment in time- - a logic that also reveals to the subject "itself" as something unfamiliar. And indeed, for Saija and others whom I detail here, the push by rehabilitative professionals to see "conscientiousness" as this motivating force does not result in their taking up the "I" of the subject position of the statement, "I am conscientious." Rather than an unfolding of a new subject or of a new understanding of past actions and passage into the present, rehabilitees continue to question why.

This article is based on ethnographic fieldwork I conducted at rehabilitation centers, associated self-help groups, and public-health forums for burnout in 2006 and 2007. These centers were located in Helsinki and the near cities of Lahti, Espoo, and Vantaa, as well as being located in Finland's east, in Northern Karelia. In particular, I focus on informal discussions among rehabilitees during the offhours of the program, when they reflected on the rehabilitation sessions as well as their own experiences.

Recent anthropological studies of social transformation under conditions of neoliberalization see time in terms of distinct economic moments productive of "its" affect and "its" forms of belonging (e.g., post-Fordist citizenship; see Berlant 2007; Muehlebach 2011; Ong 2006). Such a perspective draws upon ideas of power informed by Michel Foucault and highlights the ability of institutional discourse to produce new kinds of subjectivity. In this framework, falling under the institutional gaze nonetheless enables individuals to resist, to demand new rights to compensation and to claim membership to a new form of biological citizenship via identifying with and through institutional discourse (Hansen and Stepputat 2004; Lemke 2001; Molé 2008; Petryna 2002; Rose 2001).

But here, I gain inspiration from anthropological theory that challenges the productive powers of institutional discipline and governmental techniques to generate subjects in its image (Hall 1996; O’Malley et al. 1997; Welker 2012). These studies focus on the unintended consequences of governmentality rather than on the power of institutions to foster new forms of agency and calculated responses to technics of control. This is where Siegel's perspective on "naming" (2006) proves invaluable. In looking at institutional power through naming-specifically the 
persistent gap between what is made visible by the "name" and what is - and how it points to the limits of self-knowledge, I contribute to ongoing examinations that seek to deessentialize being by refusing to equate the subject with what comes to name it (Good et al. 2008; Siegel 2006; Song 2006; Whitmarsh 2008). Following Ian Whitmarsh, I see the reflections and demonstrations of speechlessness by rehabilitees as not "operationalized reflection ... to achieve a flexibility that better instrumentalizes change" (2008:56), but as pointing to the limits of authoritative discourse to produce stability between what appears to be and being. Although rehabilitative programs make visible how rehabilitees should undergo a process of change and self-discovery, I see the recurring question of "why [they] worked so much" as doubt about themselves as a known (and knowable) entity that arises in the face of new possibilities of self-management and sociality opened by these techniques of discipline.

Rehabilitees like Saija and others whom I detail here responded to the institutional demand to be more "self-aware" and to shed "untimely" ideas about the workplace with speechlessness and repeated questions about the roots of their own motivation. The discovery that their orientation toward work had come from a temporally contingent social ideology (e.g., "conscientiousness") suggested that their actions were not their own. In short, it questioned the possibility for sovereign action. I argue that the rehabilitative demand for the subject to reconceptualize its relation to its past and to the present from the telos of a fetishized understanding of the "now" paradoxically subverts the very promise of a way "back into the world."

\section{BACKGROUND}

Burnout as a "new hazard" of new economic policies gained social and medical resonance in the wake of the economic crisis of the 1990s. For Finland, which at that time lost its primary trading partner, the Soviet Union, the crisis was four times the severity of what the country experienced during the Great Depression of the 1930s. The shock of the crisis legitimated a perspective among even many on Finland's political Left that the protective and nationally bound economic policies of Finnish welfare ideals were not only “outdated” (Kettunen 1998) but also inefficient and structurally problematic (Heiskala 2007). Moreover, the Left's acquiescence to criticism raised by Finnish employer groups about rigid labor laws and political intervention in business was made final when food aid reached Finnish shores from the charity bank of the European Union, an event the media treated as a moment of "national collective shame” (Salvoora-Moring 2004; Uusitalo 1996). 
Specifically, employer groups and economic policymakers pointed to the political ideal of the Finnish model of Nordic welfare that obligates the state to intervene on behalf of the workforce against the vicissitudes of the market. For these groups, this idea of welfare was ideologically driven and irrational given the need to compete in the current global market (Aslama et al. 2001). In response, the Finnish government pulled back unemployment benefits and sickness insurance and revised labor laws. Most significantly, the government made amendments to the Employment Contracts Act in 2001, scaling back protections for workers from potentially exploitative workplace agreements and allowing employers to determine the terms and contracts of their employees. Specifically, this amendment emphasized contractual differentiation and deregulation based on the needs of the employer. The new policies and amendments represent not only shifts in the role of the welfare state and of the place of politics in shaping conditions of employment but also an alteration in the ethical obligations between employers and employees.

The recession and what it came to signify as national lack increased the visibility of the present as an exceptional moment demanding a reexamination of the ideas concerning moral, ethical, and legal obligations to the common good fostered during the era of social democratic welfare. Riitta Lavikka (2004), for instance, makes explicit how neoliberalization as "modernization" increased technologization and internationalization of production in a way that transformed how workers related to each other as well as how individuals made demands on themselves. With mounting pressure to "beat" foreign competition, and with increasing differentiation in technical competence among workers, workers found neither time on the shop floor for teaching oneself new techniques nor for helping others with new machinery. Lavikka argues that in an era when workers are expected to spend personal time reading up on operating manuals to "keep-oneself-up-to-date" to keep one's job, concepts such as "work load" and "fellow" employees take on new significances. Specifically, Juha Siltala (2004), Finland's leading historian of labor, describes how the introduction of performance-based compensation and differential wage negotiation systems eroded the cohesion of workers as a united front against employers. He likens the increased workplace competition between workers to "sibling rivalry" in which workers are in mutual competition with each other for recognition from above.

The Finnish economy picked up toward the end of the 1990s with the success of the IT industry, but in contrast to the growing health of the economy, researchers at the Finnish Institute of Occupational Health saw an increase in complaints of stress and insomnia. With Finnish baby boomers projected in the next 20 years 
to drop out of productive activity, and with strong evidence pointing to the links between stress, mental health problems, and premature retirement, researchers called for better stress-coping skills among the workforce as an economic as well as a public health imperative (Hätinen 2008). It is in this context that burnout came to stand in as the key trope for public health strategies against the loss of working hours because of stress and the promotion of workplace well-being.

Estimates of the prevalence of burnout are varied. Although a 1997 study claims that nearly half of the workforce showed some symptoms of burnout, national studies cite "severe burnout" in the general Finnish population ranging from 7 percent (in 1997) to 2.5 percent (in 2000). ${ }^{3}$ According to public health researchers, the prevalence of burnout cuts across occupational groups, but is especially high among workplaces that offer little stability, low personal job control, and little social and occupational resources (Ahola and Hakanen 2007; Kivimäki et al. 2006).

Burnout is a stress-related syndrome with diffuse symptomatology and is not recognized by Finnish social security institutions as a primary disease category. Although burnout is identified by the tripartite development of cynicism, irresolvable fatigue, and reduced professional efficacy, it is also treated as a generalized condition of chronic occupational stress that takes away from the capacity of the worker across job sites (Ahola 2007; Shirom 2009; Weber and Jaekel-Reinhard 2000). Burnout as this potential loss of capacity to function by individual workers thus represents a general threat to the health of the Finnish workforce.

Thus, rather than focusing on the establishment of a specific sociodemographic map of burnout, the response to burnout by KELA is aimed at its prevention in the general workforce. On this point, Jorma Rantanen, the head of the Finnish Institute for Occupational Health, is explicit. He points to the increased uncertainty of employment created by the new economy as having added to the psychological load of workers, and that the strategy of public health to increase workplace wellbeing is not in the investigation of "definite diseases" of specific groups but in the examination of general "work ability, work motivation, and the quality of worklife in general" (Rantanen 1999:477) in the face of new workplace challenges.

The proclamation of the status of burnout as a "new hazard" by health officials, then, manifests a concern over the general efficiency of the workforce in mobilizing ambitions, career goals, and differential professional skills in ways most conducive to keeping workers out of hospitals and in the workplace. In other words, the public health attention on burnout supplements a neoliberalizing tendency to extend the logic of the market to all aspects of life: in this case, it applies this logic to investigate, 
as Foucault (2008) puts it, how the individual can best become an entrepreneur of himself.

Burnout in Finnish medical nosology reflects this perspective. Medical archives define it as a dysfunction in the ability to economize one's energies - as a condition that emerges out of the "depletion of energetic resources" (Ahola 2007; Maslach et al. 2001; Shirom 2009). Burnout, in this perspective, is not an effect of the neoliberal regime but an enabling factor. It is a risk that emerges together with the demand to think in terms of market exchange and of oneself as a resource to be managed economically. It articulates the hegemonic norm by making visible those who threaten the economic imperative as untimely individuals who fail to recognize the moral, ethical, and legal laws of exchange synchronous with the new era of competition. Thus, burnout represents an ailment inseparable from its visibility as a risk to national competitiveness. In a circular logic, burnout is because of the field of vision opened by the language of neoliberal thinking.

KELA's redefinition of the concept of disability to include the loss of indeterminate qualities such as "productivity, quality of products, innovation, capacity to handle clients, and life-long work ability" (Rantanen 1999:477), further supplements this perspective. Burnout represents just such a disability in which individuals fall short of providing those indeterminate qualities to the workplace. Thus, rather than posit this loss as a problem of new economic structures upon the individual, KELA's emphasis on the individual as the rational entrepreneur of himself as a resource points to the need for the individual to be more aware of his or her limits to work. Indeed, KELA's rehabilitative program for burnout is based on an "empowerment paradigm" that places an emphasis on the "positive ability of individuals to affect well-being" (Hätinen 2008). Within the discourse of rehabilitation, rehabilitees are recast as "clients" and as active participants of their own recovery process rather than as passive patients. As active participants, clients of rehabilitative programs for burnout are expected to take control of what motivates them to work and to reassess their career goals in manner befitting individual strengths and aptitudes. Yet, as I explore in the next section, this is not necessarily what occurs.

\section{REHABILITATION: VISUALIZING “LIFE,” LISTENING TO THE "SELF"}

Clients who attend rehabilitative programs sponsored by KELA are referred through respective occupational health physicians associated with the workplace. ${ }^{4}$ Once a recommendation by the physician within the occupational health system is 
made, the client meets with a municipal representative from KELA to be placed within a suitable rehabilitation center registered within KELA's national network. KELA subsidizes the cost of the program, and the client draws 70 percent of his paycheck for the duration of the program. Clients, often not more than ten or 12, stay for ten whole days at respective centers scattered throughout the Finnish countryside and rejoin the group after a year for another weeklong program as a follow-up.

Once admitted to a center, clients face a team of physiotherapists, a general physician and nurse, nutritionist, social worker, and a psychologist. The physician and nurse take charge of assessing the physical ability of the clients to handle the daily routine of physical exercise (e.g., stretch, water aerobics, hikes) that are held in addition to both group and individual counseling sessions with the associated psychologist at the rehabilitation center. The psychologist and the team of physiotherapists represent the most constant professional presence within the program. Clients also attend lectures on nutritional health; ergonomics; individual sessions with social workers in which they talk about workplace conflicts, domestic issues, and financial problems; and sessions with a "free-time" leader (vapaa-ajanohjaaja) who plans social activities for clients for the duration of their in-patient (or in-client) stay.

The daily schedule begins at eight in the morning and ends at four in the afternoon. KELA's plan for burnout ensures that the daily schedule includes at least one meeting with the associated psychologist, several hours of aerobics and stretch exercise, and meetings with the nurse or physician as needed by clients. Mixed into these sessions are creative cognitive exercises that were described to me by accompanying psychologists as "social rehearsals." These rehearsals often took the form of scripted social conflicts that clients were asked to enact within a controlled context. Although I had no access to private counseling sessions between the psychologist and the individual client (although I often spoke with both outside of the sessions) the rehabilitative staff encouraged me to attend most of these "rehearsals," group counseling sessions, lectures, and the physiotherapy sessions.

According to Matti, a psychologist at a center, the "rehearsals" in particular challenged individuals to open themselves up to self-examination. For example, in one such rehearsal, participants were separated into two groups lined up against the wall facing each other. Matti then asked the clients to walk slowly toward each other until they met toward the center of the room. Once they reached a point where the clients met in the middle, Matti asked them whether they would hug 
each other. At this suggestion, many of the clients hugged. Some laughed and made the act into a big joke. I saw other pairs nod at each other as if to warn the other of the impending contact before falling into each other in a big performance of enveloping arms and loud patting of the backs. Matti then asked them to think about why they decided to hug, and then to feel more comfortable about being able to say "No, I don't want to hug you," without worrying about whether or not the other person will be disappointed.

The rehabilitees then were shuffled around for a new position in two groups facing each other. The next time Matti asked them to hug in the middle of the room, Pekka and Onni, two middle-age men who had already become friends, did not hug but, instead, patted each other on the back. I followed Matti as he went up to commend them. "It's great," said Matti, “you guys have not only not hugged but you have diverted the tension of not hugging by patting each other the way you were just now!" Matti explained that the exercise was meant to reveal how social pressure pushes people to do things that they might not want to do. He highlighted Pekka and Onni as a success in that they not only thwarted a pressure to hug, but also picked up something else with which they were more comfortable doing. To me, outside of the gymnasium in which this rehearsal took place, Matti explained: "People who come here often confuse what they think is expected of them from what is really expected of them. Rehabilitation exercises like this one helps them to see that saying 'no' to others does not necessarily disappoint the other or that they have to feel bad about themselves saying it." According to Matti, the objective is twofold: to demonstrate to clients that they themselves may have a problem asserting personal demands against the expectations of another, and to help clients to see that asserting oneself does not necessarily hurt the other or result in personal guilt.

Satu, a psychologist at a different rehabilitation center, agreed with Matti's idea when I described it to her. She explained that these sorts of social rehearsals and creative exercises were vital for individuals with burnout, as she considered the "lack of self-awareness" the key feature that drove individuals to work to the point of sickness. She characterized her clients as overly concerned with the wishes and needs of others, and not being attentive enough to themselves. Satu strongly recommended me to join in a session that she claimed pushed clients to visualize their goals and themselves.

In this session, the activities leader assembled the participants in a room with a table laden with scissors, glue, magazines, and a stack of construction paper. She directed us to make a "treasure map" (aarrekartta), a map that makes visible the 
professional or life goals of the individual and to imagine what steps we could take to ensure this passage. She parceled out big batches of magazines to each participant and told us to cut out images that we like from the magazines and glue them onto the construction paper. "The key is to think about how you are now and where you might like to be," she said. "Use this map as a way to think about how and whether your present actions lead to the realization of your goal." With no further questions from the clients, she told us where she could be found and left us to the task.

After she left, many grumbled about the task as being something "for children," but the room was quiet for the hour that clients took to leaf through magazines, cut, and paste. I sat with Päivi, a schoolteacher who was one of the first to befriend me in the rehabilitation center lobby. She sat hunched over a stack of magazines, cutting slowly, deliberately, and silently. She had pasted an image of a blue sky onto construction paper. She had chosen the abstract "joy" (ilo) as her goal, and was going to assemble a large ILO out of tiny individual i's, l's, and o's. As the hour passed, she was still finding and cutting out the small individual letters from the pages from the magazine. Each tiny letter was laborious to cut out of the magazine, and she needed many to assemble her larger word. I moved in to help her to cut out more letters, as did other clients who had already finished. Silently, Päivi began to cry, but continued cutting letters. After she had finally pasted ilo onto the paper, she looked over at the mounting pile of leftover letters, $i, 1$, and $o$ strewn across the table and remarked to me: "I wonder how my life started to fall apart."

As Satu intended, the demand to make a "treasure map" provoked Päivi into self-analysis. But it is not the sort of self-analysis that Satu had intended. It is not a concrete path to a "dream" or a successful path back to the workplace. Rather, her quixotic quest to assemble the word ilo from piles of tiny letters ends with tears, frustration, and a feeling of obligation to her fellow rehabilitation clients who joined her in cutting letters or sat politely waiting for her to finish so that they may all leave the room together. Päivi's breakdown reveals not a sense of new becoming as it is propped up by the staging of controlled social conflict or by the construction of the "treasure map" as a conceptual map of transformation, but a slippage between rehabilitative intent and outcome. It is a slippage that not only grounds potential for self-authorized action, as in the case of Pekka and Onni who came up with their "own" strategy of compromise, but one that also provokes participants to question their own ontological status as individuals trapped within temporally contingent demands to "be" a certain way. 


\section{THE LOBBY}

The "map" and its demand to visualize one's life goals provokes Päivi into a spiral of self-analysis, but one that diverges from the certainty of cause and effect offered by the rehabilitative discourse. Päivi asks: "I wonder how my life started to fall apart." The "how" according to Satu and other rehabilitative experts would seem to lie in Päivi's overattention to small details and in the inefficiency to get things done. But such an idea is not what grounds Päivi's question.

In Päivi's rehabilitation center, like in many others, the lobby became a place for clients to gather after hours. These nightly discussions provided the space where clients felt comfortable about posing such open-ended questions. And, in contrast to official group counseling sessions, where the attendant psychologist provided analyses and feedback to the testimonies of the participants, these discussions that took place in the lobbies often had the character of monologues. Most of the rehabilitation centers in which I did research contained such a space where clients could meet outside of the formal rehabilitation context. In three of the five centers, the lobby came equipped with a small snack bar that doubled as a café open to the public (in theory, if not in practice), and the availability of alcohol and food lent a more relaxed cast to the otherwise hospital-like setting. Pekka and Olli's center sported couches and chairs laid out in small clusters. These semiprivate clusters, unlike the one large circle of the group counseling room, provided what seemed a more natural setting for participants to sit together in tight groups to engage in more intimate conversation. These discussions often began late after dinner and into the early hours of the morning when the lights went off in the center and clients were discernible only by the bluish light of the snow from outside the window. Insomnia, a common symptom of many diagnosed with burnout, drew individuals together, and it was under such circumstance of darkness, fatigue, and the quiet of a center after closing hours that these discussions took place.

"I don't know how but I found myself working and working and working and working," said Olli at one such a nighttime assembly. He worked for an IT company, and his list of favors he conducted for the sake of others ran as long as that of Saija's. Olli addressed himself partially to me, but also to anyone who might be listening. The darkness of the lobby made it hard to discern what was addressed to whom, making it more acceptable to break into otherwise private conversations, and individuals often jumped from island of conversation to island. Miia, a middle-age woman sitting with us, chided Olli: "It's no use asking such a thing. My family used to ask me why I worked so much, but for me it wasn't the work. My supervisor even asked me whether I wanted to take a break, but I 
didn't even take it! Somehow I felt like I couldn't stop working.” Pekka, who sat not far from us, added, "It's hard to know when you have done enough. I mean, I don't know what is a normal amount of work anymore." At this, there was a general grumble of agreement from individuals whose faces I could not distinguish in the gloom. Olli's voice rose above the others: "Nothing is normal," he said. Miia agreed: "We are not normal," she said.

Miia's analysis brought silence. Some of those who had turned around in their couches to face us turned back in their seats. Olli looked away, and while I tried to get Miia's attention, she ignored me. This concern with the loss of "normalcy" was not limited to that night. Pekka brought it up again the next night, when he wondered aloud how he "found [him]self working." This time, Pekka repeated this connection within a larger analysis of his own experiences at his previous place of work as well as at the rehabilitation center. I asked him about it, and he slid over one of the many tall glasses of beer he had purchased before the little kiosk closed for the night. Pekka told me that his main complaint of sleeplessness began in the late 1990s, just as he landed a position in the growing IT industry. In the wake of the economic recession, a job in the industry that represented for many Finns the future of the country was something of prestige. But it also overwhelmed him. With a little exaggeration, he said he did "[with his four colleagues] what a hundred workers should do." He quit after four years, and chose to work at a place that he loved: the local hockey rink in his hometown on the Gulf of Bothnia. But his problems followed him.

Although the amount of work he felt he had to complete at the IT company led to his decision to move to the more - as he thought at the time- "relaxing" position at the local ice rink, at this place, too, his work piled up and his symptoms got worse. At the rink, his sleeplessness reached intolerable levels and he confessed that before attending the rehabilitation program he fantasized about ending his life. "I started to think that I was a bad person. I just wanted to end it all," he said. Pekka confessed that the situation at the ice rink was far worse owing to the added frustration of knowing that he had quit his more prestigious (and lucrative) position at the IT company for a position that he thought would be easier. He saw himself as the only constant between the new and the old places of work, and he started to blame himself for the conflicts he had at his previous workplace at the IT firm, reasoning that the repetition of the problems at his two workplaces meant that something was wrong with him. As his insomnia worsened, he described working days filled with torpor and irritation that led to more guilt and insomnia. 
Pekka described one weekend when, in an effort to maintain his "sanity," he worked 27 hours to keep abreast of what needed to be done at the ice rink. Throughout, he told himself that the work at the ice rink was supposed to be "relaxing," that he should be able to do the tasks at the rink more easily. Resisting the growing feeling that he was alone responsible for his plight, Pekka confronted his supervisor, asking him for, as he put it, "better management" in the assignment and ordering of his tasks. Pekka described to me how his supervisor looked up and said bluntly, "take it or leave it."

It was then that Pekka began to think about death. From his retrospective vantage point at the rehabilitation center, he no longer believed he was necessarily "bad," but that as rehabilitative professionals told him, "overly conscientious." Pekka described how a perceived need to "complete [his] tasks filled [his] head . . . drove [him] mad." Yet, although he now sees himself as "conscientious," he sees no solution in moderating his feelings of obligation, as the rehabilitation center would have him do. Nor does he forge an identity as a righteous victim, a bastion of moral “conscientiousness" in the face of a rapacious profit-minded present. "I just don't think I can go back to work [at the rink, or anywhere]," he said. It was a point he repeated toward the end of the rehabilitative program. "I don't think I can even go back home." When I pressed him, he explained:

I just don't know what's normal anymore. Even as a child, I was taught to complete my tasks. I want to do all the tasks that I am supposed to do. But there is an imbalance today, because there are things that you want to do but not enough time to do them all. There isn't enough capacity in my head to juggle all these obligations. I feel that if you get your head filled up with these worries, you will lose your will to live, your life. . . The rehabilitation program [has] given me the tools to talk about what I went through but I don't think I can explain how I feel to my family.

The rehabilitative language of burnout provides him with the "tools" to talk about his distress, yet it falls short of guaranteeing for Pekka a way back home. Pekka's turn to the concrete and rational explanations offered by rehabilitative professionals for his symptoms are counterbalanced by his afterthoughts in which he continues to examine himself and his motivation.

Several questions arise from Pekka's story. Why did Pekka not push his point with his supervisor at the ice rink? Why should he "lose his will to live" soon after? How are we to understand his sense of self-ineffectuality and inability to project himself forward within the social? 
Pekka complains that it is not "anymore" that he knows what is "normal" - a condition he makes explicit here as one in which he knows what he is "supposed to do." Pekka attempts to confront his supervisor at the ice rink, but he does not push his point against his supervisor's blunt answer. Against this response, Pekka speaks of death and of not knowing. Naming what made sense to Pekka as "conscientiousness," linked to a moral consciousness inculcated to him as a child, does not restore for him the capacity to move on. The retrospective construction of himself as constituted by these properties ironically reveals himself as someone alienated from his own needs. What made sense as self-grounded acts reappear under the imperative of the rehabilitative discourse to rethink what motivates (and motivated in the past), as something "externally" grounded. What he thought were sovereign actions - his own moral choices - in retrospect appear to be coming from a past impetus to "complete" tasks or "be conscientious," a property rehabilitative professionals make visible that he was not aware of. The conflict with his supervisor and the rehabilitative demand to rethink his actions then destabilize not only what he thought he was "supposed to do," but himself as a self-authorizing agent.

I see Pekka's losing the will to live as connected to this awareness of himself as opened up to social judgment that remains beyond his control but that nonetheless dictates the conditions on which how to "belong" - that is, knowing what one is "supposed to" - is at stake. What the rehabilitative demand and the conflicts at work reveal then, is a horror of the social and of the impossibility of mastering its rules as one's own. What haunts him is not the disciplinary power of the institution or the workplace per se, but the very revelation of the social as an inherently disciplinary space.

\section{METAMORPHOSIS}

Pekka's sense of self-ineffectuality illuminates much of these off-hours discussions at the rehabilitation center. It is in the spirit of these discussions that I return to Saija.

Saija spoke positively of the temporal and social distance the rehabilitative program gave her from her everyday life. After the end of the daily schedule, Saija and others from the program congregated at a lakefront café. When I asked Saija to describe to me in more detail her experience with burnout, she began by talking about the day when her two coworkers left her to tend to the phones alone all morning. "Something inside me snapped," Saija said. "I couldn't take being a garbage bin any longer. I rushed into my supervisor's office yelling, screaming and crying a lot." Her supervisor called in an upper-level manager for support, and 
asked Saija to tell them what they could do to keep her at work. But this direct question by the upper-level manager made her suddenly quiet. "I stopped shouting and I just cried. I became quite quiet," she said. She described how she went back to her desk without saying a word. That whole week she worked as if nothing had happened, but during the weekend, she said that she felt a change come over her. "I found that the most I could do was to haul myself from the bed to the couch. I just sat there. I couldn't pick up the phone, I couldn't leave the apartment. I just sat on my couch looking at my ceiling. I felt as if I were wrapped in plastic [muovikäärössä],” she said.

Although rehabilitative professionals pointed to Saija's distress as something that stemmed from her sense of responsibility and conscientiousness, Saija instead presents the problem as an inability to communicate despite a desire to do so. When faced with the opportunity to speak directly to power, she found she could not put into words what she had intended to communicate. It is in the face of such an inability that she finds herself "wrapped in plastic."

"Something inside me snapped," said Saija of being put in the position of a "garbage bin," a person upon whom tasks could be dumped. Yet, why does Saija, like Pekka, fall short of pushing their point when faced with the opportunity to speak? What accounts for this loss of capacity?

Her idiom of being "wrapped in plastic" shows a transformation of Saija from an agent to a spectator of her own self, a condition that continues into, and is even encouraged by, the rehabilitative program and its focus on self-objectification. Saija repeats a phrase by other rehabilitees during the nighttime assemblies, in describing the day she felt herself thus "wrapped," as "finding herself unable to get out of bed" (recall Olli's having "found [him]self working and working”). Such a construction that emphasizes accident and the perception of oneself as an object of discovery underlines the type of alienation echoed by many rehabilitees. "Finding oneself," as an expression, also points to self-division, of doubling and of looking at the self from the "outside." But, as we see from the individuals introduced so far, this "outside" is a nonlocatable space. This space from which they look on themselves originates neither from a new subject position as a "conscientious individual" nor as a victim of workplace circumstance.

The rehabilitation center as a space "away from life," as the director at Saija's center described it, and rehabilitative practices both facilitate self-reflection. This process of reflection under the rehabilitative program is encouraged through the presumption of rehabilitees as having worked in a manner that failed to take selfneed into account. Yet, what rehabilitees reveal through stories of speechlessness 
and confusion at having "somehow" continued working is a subversion of the very presumption of a self (e.g., as an empirical entity with specific needs) waiting to be restored. Instead, the very idea of the self as an object of knowledge is placed under investigation.

"I couldn't take being a garbage bin any longer," Saija says, yet she finds herself unable to speak to her supervisor. Again, she falls uncomfortably speechless when asked by Iiris (at the beginning of this article) why she felt she had to pick up after her coworkers. Her silence then, is not mere emptiness, but a manifestation of a desire to speak that does not make it into words. As Siegel (2006:68) argues, such moments of speechlessness demonstrate that that which is left out of language nonetheless exists. Had she no doubts about her actions and herself as the author of her actions, she would know how to explain why it is that she worked as much as she did. She would also have an idea of what she would like to have said to her supervisors. Speechlessness occurs precisely because of an awareness of one's own inadequacy in explaining why one did what one did. The condition of "something snapping," as in Saija then, points not only to frustration against her coworkers, but also against her own inability to explain how she got to become the "garbage bin" in the workplace.

Eeva, another participant I became close to through Saija, described her sense of "being wrapped in plastic" as a desire for death. "It's not the work," she said. "I love my work. But it's about waking up one morning and wondering why you do all these things. One day, I woke up and I just lay there. I thought about killing myself, only that it felt like I was already dead.”

The recurring themes of speechlessness, or in the cases of Eeva and Pekka, an encounter with the idea of death, then do not merely appear as a result of conflicting perspectives at work but from an awareness of a certain limit in one's own understanding of oneself. For, without this sense of limit and anxiety concerning one's own actions, Saija and others would have recourse to pushing their point further rather than falling silent. Death and ineffectuality appear at the horizon of language and one's belief in one's capacity to act as a sovereign - that is, to act without being caused to act. It is in looking back and finding oneself estranged, and unable to self-authorize one's actions (to name oneself the cause of one's action), that I see Eeva, Saija, and others find themselves as products of the social and lost to themselves.

These experiences recall the inexplicable sense of alienation and dislocation described by Franz Kafka in “The Metamorphosis” (1948). In Kafka’s story, Gregor Samsa is a clerk who wakes up one morning to find himself suddenly and without 
warning or reason transformed into an insect, unable to speak and an object of revulsion to his family. It is a metamorphosis that begins with his spectatorship of himself as something made alien. And it is this form of spectatorship and the self as an impossible object of the name that undercuts the ability of rehabilitees to "get back into the world.”

\section{CONCLUSION}

These quiet reflections on the "self" during breaks in the rehabilitative schedule demonstrate how the rehabilitative imperative to rethink the "self" in relation to present-day exigencies instead brings into radical doubt ideas of the self, sociality and ethics of exchange as such beyond their differential manifestations through time. Shifts in economic and political thinking about productivity often lead to discussions about life in the present as something different, and in need of objective assessment. As recent scholarship on the effects of social transitions toward neoliberal economic thinking shows (Han 2004; Muehlebach 2011; Nelson 1999), such an effort to redefine the social contracts, ethics, and ideals of production involves much more than the mere pragmatics of adopting new practices but the internalization of specific forces presumed to animate the subject. Everyday life, which hitherto remained veiled in its very familiarity appears in such a context to be something else-_faster," "harder," or "more dangerous" than what came before it. But those whom I have introduced here show that this focus on what appears different fails to name and to contain what makes social life as such a risky and alienating engagement.

For many individuals I came to know at the rehabilitation centers, their diagnosis, rather than produce a way to take control of the dangers of accepting work beyond one's self-limits, unveils the possibility that something remains beyond such attempts at domestication. Why they voluntarily worked to the extent that they did on reflection fails to be contained within the sources identified and named via the rehabilitative discourse of burnout. I argue that it is in such instances that categories of understanding such as burnout and conscientiousness stand in as fetishes to make accessible and iterable this "something else at work" as Siegel (2006) puts it, yet keeps what remains left out of its formulation safely veiled.

As Nikolas Rose argues, experts, based on their claim to objective scientific knowledge, "inculcat[e] desires for self-development that expertise itself can guide and through claims to be able to allay the anxieties generated when the actuality of life fails to live up to its image" (Rose 1999:88). Yet here, I present a case in which such expertise does not just fail to resolve for clients the sense of dislocation from themselves as the very demand to know themselves estranges themselves from 
"themselves" in a way that, counter Foucault (Elden 2001:104), the subjection of the body does not form the subject. In contrast, the productive power of a metanarrative of time and of belonging, such as the discourse of burnout, lies within its ability to incite anxiety about the self as always already fashioned, fabricated, and caught within temporally contingent technologies through which we come to see ourselves seeing ourselves (Song 2006). Such a perspective has implications for rethinking the power of expert knowledge, illness narratives, and the effectiveness of symbols to resolve anxiety about the origins of distress in a way that empowers the subject.

\begin{abstract}
Coming out from the shadow of the economic crisis of the 1990s, the neoliberalizing Finnish state identified another emergent threat: "burnout," a mental disorder characterized by cynicism and loss of productivity affecting nearly all strata of the workforce. Efforts to identify and rehabilitate workers focused on improving "self-awareness," and having individuals reevaluate their relationship with and expectations of society. For many Finnish mental health professionals, burnout stemmed from individuals who were too "conscientious," holding attitudes that were increasingly maladaptive in the new competition-oriented economy. Yet for many in rehabilitation centers, calls to "know yourself" paradoxically generated questions about being, and the challenge to come into oneself as a sovereign, beyond these temporally contingent constructions. Many of those under rehabilitative care spoke of finding themselves estranged and metamorphosized in the face of a diagnosis that presented themselves to themselves as an entity yet to be discovered. In this way, rather than focus on the generative potential of institutional categories to construct new subject identities, I instead locate their power in their capacity to open up to examination that which they name. [subjectivity, alienation, emergent disorder, neoliberalism, sovereignty]
\end{abstract}

\title{
NOTES
}

Acknowledgments. I am indebted to the input of Dominic Boyer, Andrew Willford, and Magnus Fiskesjö on work of which this article is a part. I wish to thank Andrew Johnson for many inspirational conversations about the concepts that went into this article. Sincere thanks also go to James Siegel, Hoon Song, and David Rojas for their invaluable comments at critical moments in writing this article. I am indebted to the editors of Cultural Anthropology and the two anonymous reviewers for their careful reading and thoughtful comments that helped clarify the argument. Finally, I wish to thank Juha Siltala and Jukka Tontti from the University of Helsinki for their support, as well as the staff at rehabilitation centers who allowed me into their daily operation and the attendees who shared with me their experience. This article comes out of work generously funded by the IIE-Fulbright Award and the Wenner-Gren Foundation for Anthropological Research.

1. Those undergoing rehabilitation for burnout were explicitly not referred to as patients. Instead, rehabilitation centers often termed them clients. Here, I use the latter term as well as the general rehabilitees. 
2. This is based on the national blueprint for rehabilitation programs for burnout as developed by KELA during the time of this research in 2007.

3. See Kalimo and Toppinen 1997.

4. Finnish employers are obligated by law to provide occupational healthcare for their employees at their expense. They can hire private occupational health physicians or purchase occupational health services from municipal health centers. Further, employers can develop their own occupational health care unit, or, together with other employers, set up a joint occupational health unit that serves employees from multiple workplaces.

\section{REFERENCES CITED}

Ahola, Kirsi

2007 Occupational Burnout and Health. People and Work Research Reports, 81. Finnish Institute of Occupational Health. Tampere: Tampereen Yliopistopaino Oy.

Ahola, Kirsi, and Jari Hakanen

2007 Job Strain, Burnout and Depressive Symptoms: A Prospective Study among Dentists. Journal of Affective Disorders 104(1):103-110.

Aslama, Minna, Anu Kantola, Ullamaija Kivikuru, and Sanna Valtonen

2001 Politics Displaced, Politics Replaces, Elites' and Citizens' Talk on the Economic Crisis. In Down from the Heavens, up from the Ashes: The Finnish Economic Crisis of the 1990s in the Light of Economic and Social Research. Jorma Kalela, Jaakko Kiander, Ullamaija Kivikuru, Heikki Loikkanena, and Jussi Simpura, eds.

Berlant, Lauren Pp. 168-188. Helsinki: Gummerus Kirjapaino Oy.

2007 Nearly Utopian, Nearly Normal: Post-Fordist Affect in La Promesse and Rosetta. Public Culture 19(2):273-301.

Elden, Stuart

2001 Mapping the Present: Heidegger, Foucault and the Project of a Spatial History. New York: Continuum International.

Foucault, Michel

2008 [2004] The Birth of Biopolitics. Lectures at the College de France, 1978-79. New York: Palgrave Macmillan.

Good, Byron, Mary-Jo DelVecchio Good, Sandra Teresa Hyde, and Sarah Pinto

2008 Postcolonial Disorders: Reflections on Subjectivity in the Contemporary World. In Postcolonial Disorders. Mary-Jo DelVecchio Good, Sandra Teresa Hyde, Sarah Pinto, and Byron Good, eds. Pp. 1-42. Berkeley: University of California Press.

Hall, Stuart

1996 Introduction: Who Needs "Identity"? In Questions of Cultural Identity. Stuart Hall and Paul Du Gay, eds. Pp. 1-17. London: Sage.

Han, Clara

2004 The Work of Indebtedness: The Traumatic Present of Late Capitalist Chile. Culture, Medicine and Psychiatry 28:169-187.

Hansen, Thomas, and Finn Stepputat

2004 Sovereignty Revisited. Annual Review of Anthropology 35:295-315.

Heiskala, Risto

2007 Social Innovations: Structural and Power Perspectives. In Social Innovations, Institutional Change and Economic Performance. Timo J. Hämäläinen and Risto Heiskala, eds. Pp. 52-79. Northampton, MA: Edward Elgar.

Hätinen, Marja

2008 Treating Job Burnout in Employee Rehabilitation. Changes in Symptoms, Antecedents, and Consequences. Ph.D. dissertation, Department of Psychology, University of Jyväskylä.

Kafka, Franz

1948 The Metamorphosis, the Penal Colony, and Other Stories. New York: Schocken. 
Kalimo, Raija, and S. Toppinen

1997 Työuupumus Suomen Työikäisellä Väestöllä [Prevalence of burnout in the Finnish working population]. Helsinki: Finnish Institute of Occupational Health.

Kettunen, Pauli

1998 Globalization and the Criteria of "Us"-A Historical Perspective on the Discussion of the Nordic Model and New Challenges. In Global Redefining of Working Life-A New Nordic Agenda for Competence and Participation? Daniel Fleming, Pauli Kettunen, Henrik Søborg, and Christopher Thörnqvist, eds. Pp. 33-80. Copenhagen: Nordic Council of Ministers.

Kivimäki, Mika, Marianna Virtanen, Marko Elovainio, Anne Kouvonen, Ari Väänänen, and Jussi Vahtera

2006 Work Stress in the Etiology of Coronary Heart Disease: Systematic Review and Meta-Analysis of Prospective Cohort Studies. Scandinavian Journal of Work Environment Health 32:431-442.

Lavikka, Riitta

2004 Fulfillment or Slavery? The Changing Sense of Self at Work. In Information Society and the Workplace: Spaces, Boundaries and Agency. Tuula Heiskanen and Jeff Hearn, eds. Pp. 143-177. London: Routledge.

Lehto, Anna-Maija

2007 Finnish Quality of Work Life Surveys. European Foundation for the Improvement of Living and Working Conditions. http: / /www.eurofound.europa.eu, accessed March 2, 2008.

Lemke, Thomas

2001 "The Birth of Biopolitics": Michel Foucault's Lecture at the Collège de France on Neo-Liberal Governmentality. Economic and Society 30(2):190-207.

Maslach, Christina, Susan Jackson, and Michael Leiter

Molé, Noelle

2001 Job Burnout. Annual Review of Psychology 52:397-422.

2008 Living It on the Skin: Italian States, Working Illness. American Ethnologist 35(2): 189-210.

Muehlebach, Andrea

2011 On Affective Labor in Post-Fordist Italy. Cultural Anthropology 26(1):59-82.

Nelson, Diane

1999 A Finger in the Wound: Body Politics in Quincentennial Guatemala. Berkeley:

University of California Press.

O'Malley, Pat, Lorna Weir, and Clifford Shearing

1997 Governmentality, Criticism, Politics. Economy and Society 26(4):501-517.

Ong, Aihwa

2006 Neoliberalism as Exception: Mutations in Citizenship and Sovereignty. Durham, NC: Duke University Press.

Petryna, Adriana

2002 Life Exposed: Biological Citizens after Chernobyl. Princeton: Princeton University Press.

Rantanen, Jorma

1999 Research Challenges Arising from Changes in Worklife. Scandinavian Journal of Work Environment Health 25(6):473-483.

Rose, Nikolas

1999 Powers of Freedom: Reframing Political Thought. Cambridge: Cambridge University Press.

2001 The Politics of Life Itself. Theory, Culture and Society 18(6):1-30.

Salvoora-Moring, Inka

2004 Media Geographies: Regional Newspaper Discourses in Finland in the 1990s. Ph.D. dissertation, Department of Communication, University of Helsinki. 
Shirom, Arie

2009 Burnout and Health: Expanding Our Knowledge. Stress and Health 25:281-289.

Siegel, James

2006 Naming the Witch. Stanford: Stanford University Press.

Siltala, Juha

2004 Aggression at Work: From Structured Labour Market Conflict to Inter- and Intra-Personal Tension. Organisational and Social Dynamics 4(1):46-66.

Song, Hoon

2006 Seeing Oneself Seeing Oneself: White Nihilism in Ethnography and Theory. Ethnos 71(4):470-488.

Uusitalo, Hannu

1996 Economic Crisis and Social Policy in Finland in the 1990s. Social Policy Research Centre (SPRC) Discussion Paper, 70 October. Sydney: University of New South Wales.

Weber, Andreas, and A. Jaekel-Reinhard

2000 Burnout Syndrome: A Disease of Modern Societies? Occupational Medicine 50(7):512-517.

Welker, Marina

2012 The Green Revolution's Ghost: Unruly Subjects of Participatory Development in Whitmarsh, Ian Rural Indonesia. American Ethnologist 39(2):389-406.

2008 Biomedical Ambivalence: Asthma Diagnosis, the Pharmaceutical, and Other Contradictions in Barbados. American Ethnologist 35(1):49-63. 